\title{
Catastrophic shifts in the aquatic primary production revealed by a small low-flow section of tropical downstream after dredging
}

\author{
H. Marotta ${ }^{a, b, c *}$ and A. Enrich-Prast ${ }^{d, e}$ \\ ${ }^{a}$ Laboratório de Processos Sedimentares e Ambientais - LAPSA/LINCGlobal, Departamento de Geografia, Instituto de \\ Geociências, Universidade Federal Fluminense - UFF, CEP 24210-340, Niterói, RJ, Brazil \\ 'Programa de Pós-graduação em Geografia, Universidade Federal Fluminense - UFF, CEP 24210-340, Niterói, RJ, Brazil \\ 'Programa de Pós-graduação em Geociências/Geoquímica, Universidade Federal Fluminense - UFF, \\ CEP 24210-340, Niterói, RJ, Brazil \\ ${ }^{\mathrm{d}}$ Laboratório de Biogeoquímica, Departamento de Ecologia, Instituto de Biologia, Universidade Federal do Rio de Janeiro \\ - UFRJ, Cidade Universitária, s/n, CP 68020, CEP 21941-970, Rio de Janeiro, RJ, Brazil \\ ${ }^{\mathrm{e}}$ Department of Thematic Studies - Environmental Change, Linköping University, Zip Code 58183, Linkoping, Sweden \\ *e-mail: humbertomarotta@id.uff.br
}

Received: December 10, 2013 - Accepted: May 7, 2014 - Distributed: November 30, 2015

(With 5 Figures)

\begin{abstract}
Dredging is a catastrophic disturbance that directly affects key biological processes in aquatic ecosystems, especially in those small and shallow. In the tropics, metabolic responses could still be enhanced by the high temperatures and solar incidence. Here, we assessed changes in the aquatic primary production along a small section of low-flow tropical downstream (Imboassica Stream, Brazil) after dredging. Our results suggested that these ecosystems may show catastrophic shifts between net heterotrophy and autotrophy in waters based on three short-term stages following the dredging: (I) a strongly heterotrophic net primary production -NPP- coupled to an intense respiration -R- likely supported by high resuspended organic sediments and nutrients from the bottom; (II) a strongly autotrophic NPP coupled to an intense gross primary production -GPP- favored by the high nutrient levels and low solar light attenuation from suspended solids or aquatic macrophytes; and (III) a NPP near to the equilibrium coupled to low GPP and R rates following, respectively, the shading by aquatic macrophytes and high particulate sedimentation. In conclusion, changes in aquatic primary production could be an important threshold for controlling drastic shifts in the organic matter cycling and the subsequent silting up of small tropical streams after dredging events.
\end{abstract}

Keywords: primary production, catastrophic shifts, dredging, tropical streams.

\section{Mudanças catastróficas na produção primária aquática revelada por uma pequena seção de baixa vazão a jusante de um riacho após dragagem}

\begin{abstract}
Resumo
Dragagem é um distúrbio catastrófico que afeta diretamente processos biológicos chave nos ecossistemas aquáticos, especialmente naqueles pequenos e rasos. Nos trópicos, as respostas metabólicas podem ser ainda mais intensificadas pelas altas temperaturas e incidência solar. No presente estudo, avaliamos mudanças na produção primária aquática ao longo de uma pequena seção de um riacho tropical após uma dragagem (riacho Imboassica, Brasil). Nossos resultados sugeriram que estes ecossistemas podem apresentar mudanças catastróficas desde heterotrofia à autotrofia líquida na água, baseadas em três etapas de curto prazo após a dragagem: (I) uma produção primária líquida -PPL- fortemente heterotrófica associada a uma intensa respiração -R-, provavelmente sustentada por sedimentos orgânicos e nutrientes advindos do fundo; (II) uma PPL fortemente autotrófica associada a uma intensa produção primária bruta -PPBfavorecida pelos elevados níveis de nutrientes e baixa atenuação da luz solar pelos sólidos em suspensão ou macrófitas aquáticas; e (III) uma PPL próxima ao equilíbrio associada às reduzidas taxas de PPB e R seguindo os sombreamento pelas macrófitas aquáticas e elevada sedimentação de particulados. Como conclusão, mudanças na produção primária aquática poderiam ser um importante limiar para controlar drásticas alterações na ciclagem da matéria orgânica e no subsequente assoreamento de pequenos riachos tropicais após eventos de dragagem.
\end{abstract}

Palavras-chave: produção primária, mudanças catastróficas, dragagem, riachos tropicais. 


\section{Introduction}

The overall imbalance between gross primary production (GPP) and respiration (R) is commonly reported in ecosystems around the world, resulting in severe implications for the global carbon (C) cycling (Chapin III et al., 2006). The sum between C fixation by GPP and organic degradation by $\mathrm{R}$ is named net primary production (NPP), which may be highly dynamic in natural waters following natural or anthropogenic processes. Fluctuations in ecological conditions, such as temperature (Wohlers et al., 2009) and salinity (Hartzell and Jordan, 2012), or resources, such as solar radiation (Williamson et al., 1999), organic substrates (Azam, 1998; Ram et al., 2003) and nutrients (Duarte and Agusti, 1998; Biddanda et al., 2001), determine substantial changes in pelagic metabolic rates over space and time. Previous studies at low latitudes have found out that both magnitude and variation of biological processes involved in the organic matter cycling in inland waters are potentially enhanced by higher temperatures (Marotta et al., 2009b, 2010b; Dillon et al., 2010).

Temporal changes in metabolic pathways may be intense, but are still poorly understood in aquatic environments due to constraints to assess them over short- (Staehr and Sand-Jensen, 2007) and long- (Engstrom et al., 2000) term periods. An alternative to reduce constraints for ecological studies throughout the time is by using the chronosequence scale in the space, which represents a series of sites varying in age since surface formation or catastrophic disturbance, but with all other extrinsic driving factors being relatively constant (Wardle et al., 2004). Although restricted to peculiar sites, ecologists have used chronosequences since pioneer papers (Cowles, 1899; Lowrie, 1948) and currently for terrestrial (Lichter, 1998; Wardle et al., 2004; Zona et al., 2010) and aquatic (Engstrom et al., 2000; Nislow and Lowe, 2006) environments.

In the watershed, the human land use has increased substantially nutrient inputs (Knoll et al., 2003; Schindler, 2006) and deforestation (Davidson et al., 2012), drivers positively related with sediment load to the aquatic ecosystems. The subsequent depth reduction followed by water quality and biodiversity loss has made shallow streams particularly sensitive to these anthropogenic disturbances (Casatti et al., 2006; Rörig et al., 2007). Also, the silting up of shallow inland waters may be still intensified by the growth of aquatic primary producers (Moreira-Turcq et al., 2004), especially under eutrophic conditions (Marotta et al., 2009a). In this way, dredging is a common man-made intervention to mitigate silting up processes (Bemvenuti et al., 2005; Jiang and Shen, 2006). This catastrophic disturbance causes intense metabolic changes following a drastic sediment removal and resuspension (Lohrer and Wetz, 2003). Here, we assessed changes in the pelagic NPP along a short chronosequence after dredging in a small section of low-flow tropical downstream.

\section{Methods}

\subsection{Study area}

The Imboassica Stream $\left(22^{\circ} 25^{\prime} \mathrm{S}\right.$ e $\left.42^{\circ} 55^{\prime} \mathrm{W}\right)$ is a small fourth order tropical stream with low flow and about $14 \mathrm{~km}$ in length, the main tributary of the Imboassica Lagoon watershed $\left(\right.$ area $=55 \mathrm{~km}^{2}$; Marotta et al., 2009a) in the North of Rio de Janeiro state (Southeast of Brazil, Figure 1). The low flow of this stream reflects the low altitudinal gradient from the spring to the mouth, as $90 \%$ of the extension is between 0 and $40 \mathrm{~m}$ (maximum altitude $120 \mathrm{~m}$ ). We studied the downstream section next to its mouth into the lagoon, a mesotrophic coastal ecosystem receiving anthropogenic nutrient inputs (Marotta et al., 2010a). The predominant land use in the whole Imboassica Lagoon watershed is abandoned pasture fields with fragments of native Atlantic Forest, although lowlands are dominated by the urban use. The mean temperature of this area ranges from $21^{\circ} \mathrm{C}$ in July and $26^{\circ} \mathrm{C}$ in February (INMET, 1992). Despite highly variable among years (Carmouze et al., 1991), the minimum and maximum monthly rainfall are typically observed in August $(38 \mathrm{~mm})$ and December (182 mm; INMET, 1992).

Before the dredging activities, the mouth of the Imboassica Stream into Imboassica Lagoon had showed an intermittent water column and dense colonization by the emergent aquatic macrophyte Typha domingensis Pers (Marotta et al., 2009a). From June to September 2002, a dredging removed the $T$. domingensis stand together with a large amount (4-5 m height and 8-10 m width) of peat sediments (Figure 2). This dredging resulted in a perennial water column, with a depth of $0.9 \mathrm{~m}$ and a very low flow not detected by the $2031 \mathrm{H}$ flowmeter (water flow $<0.1 \mathrm{~m} \mathrm{~s}^{-1}$ ).

\subsection{Study design and sampling stations}

During 120 days before the sampling, the very low flow and turbulence coupled to the absence of rainfall and affluent inputs contributed to form a short-term aquatic chronosequence in the section of Imboassica Stream near to Imboassica Lagoon. Different conditions at this fluvial section (as nutrient and suspended solid in waters) were mainly a result of the progressive changes through time following the dredging. A strong rainfall homogenized all extension of the Imboassica downstream by increasing the fluvial flow, ending with the studied chronosequence, only ten days after our sampling.

The sampling stations were situated along a linear 1200-m extension of the Imboassica stream near to its mouth. The dredge withdrew sediments in a constant rate of $10 \mathrm{~m} \mathrm{~d}^{-1}$ during 120 days. Six sampling stations were simultaneously collected: St 02 , St 15 , St 30 , St 60 , St 90 and St 120. These stations represented a short-term chronosequence with different distances from the dredge and subsequent days after dredging (Figure 2).

\subsection{Analytical methods}

We estimated pelagic GPP, R and NPP from changes in dissolved oxygen (DO) concentrations by the light-dark bottle method (Wetzel and Likens, 2000). Water samples 

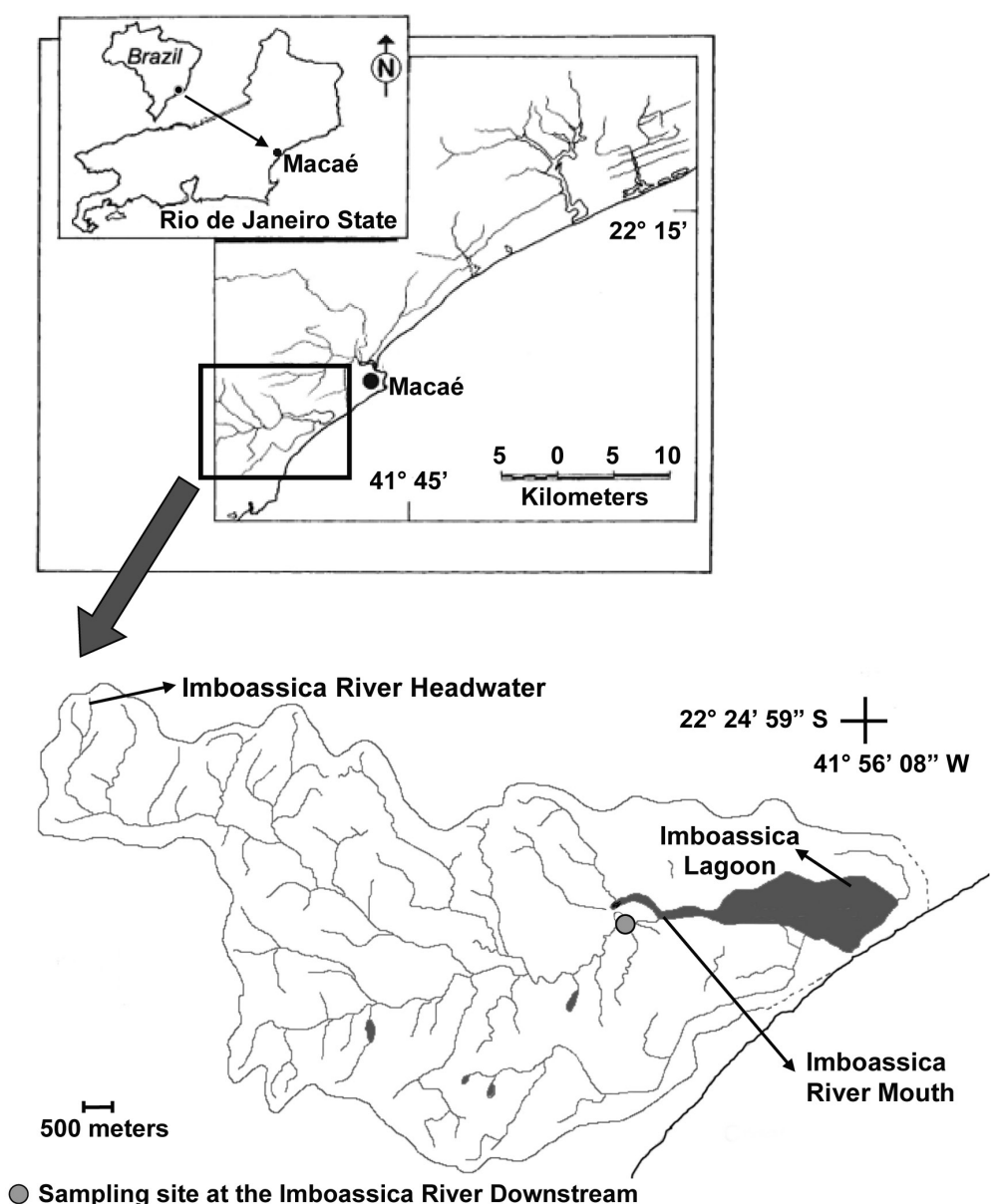

Figure 1. Geographic location of the sampling site in the Imboassica lagoon watershed.

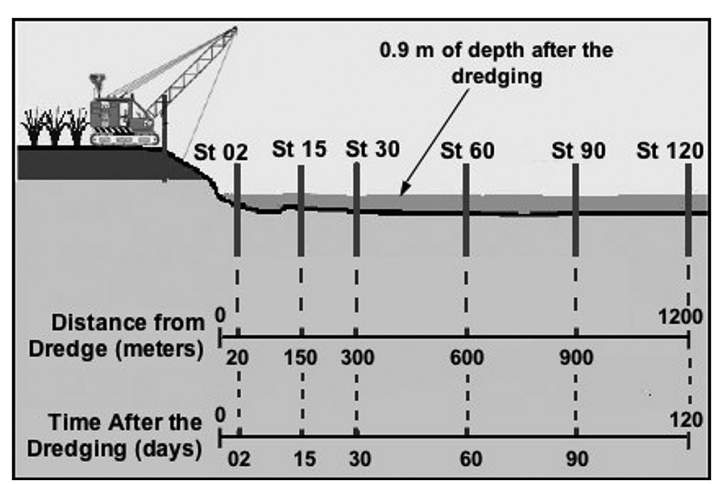

Figure 2. Sampling stations along the short-term chronosequence in the Imboassica Stream.

were taken at intermediate depth in each station and enclosed in four replicates for each bottle type (transparent or opaque) and placed in situ. NPP and R were estimated from changes in DO during 24 hours in transparent and opaque bottles respectively. GPP was calculated from the sum of NPP and R during the daytime. The sampling periods to integrate daily changes in $\mathrm{O}_{2}$ were: 6-10h, 10-14h, 14-18h, and 18-6h day after. DO concentrations were quantified by Winkler's titration (Wetzel and Likens, $2000)$ in the field.

Water samples were transported to the laboratory and frozen for total nutrient analysis, while dissolved nutrients were determined in waters previously filtered with $0.7 \mu \mathrm{m}$ filters (Whatman GF/F) before freezing (APHA, 1992). Nitrogen concentrations were estimated by the sum between Kjeldahl N and NOx forms (Mackereth et al., 1978), and phosphorus concentrations by the blue molybdenum reaction (Golterman et al., 1978). Ammonium and NOx forms were quantified using a Flux Injector Analyzer ASIA/ISMATEC (APHA, 1992).

Total suspended solids (TSS) and chlorophyll- $a$ concentrations were determined in the filtered fraction $>0.7 \mu \mathrm{m}$ (Whatman GF/F filters). Chlorophyll- $a$ was used as a proxy for phytoplankton biomass, measured by the extraction with ethanol in the dark for $24 \mathrm{~h}$ before subsequent analyses using wavelengths of $433 \mathrm{~nm}$ for excitation and $673 \mathrm{~nm}$ for emission measurements in a spectrophotometer (Nusch and Palme, 1975). The biomass of aquatic macrophytes was determined by the harvest 
method ( $\mathrm{N}=4$ quadrats of $1 \mathrm{~m}^{2}$ in each sampling station) and drying at $60^{\circ} \mathrm{C}$ in the laboratory until constant weight. The index of macrophyte cover on the water surface was estimated by longitudinal transects $(\mathrm{N}=4)$ in each sampling station.

\subsection{Statistical approach}

Data were log-transformed to meet assumptions of parametric statistical tests (Zar, 1996), including significant normal distribution (Kolmogorov-Smirnov test, $\mathrm{p}<0.05$ ) and non-significant differences for standard deviations among sampling matrices (Bartlett test, $\mathrm{p}<0.05$ ). Statistical differences were assessed with one-way analysis of variance (ANOVA) followed by post-hoc Tukey-Kramer multiple comparisons (significant $\mathrm{p}<0.05$; Zar, 1996), using the software STATISTICA 6.0.

\section{Results}

The sampling station located closer to the dredge (St 02) showed the highest TSS and nutrient concentrations in our study (Tukey-Kramer, $\mathrm{p}<0.05$; Table 1 and Figure $3 \mathrm{a}$ ). TSS in St 02 were around fourfold higher than in St 15, where these values were also significantly higher than St 30, St 60, St 90 and St 120 (Tukey-Kramer, p<0.05; Figure 3a). Phosphorus and nitrogen concentrations (both total and dissolved forms) were between 3.5 and 10 times higher in St 02 (Tukey-Kramer, $\mathrm{p}<0.05$; Table 1). In contrast, chlorophyll- $a$ concentrations (proxy for phytoplankton biomass) were at least twice higher in St 30 than any other station, reaching $10 \mu \mathrm{g} \mathrm{L}^{-1}$ (Tukey-Kramer, $\mathrm{p}<0.05$; Figure $3 \mathrm{a}$ ). Lastly, floating aquatic macrophytes (Salvinea auriculata) colonized only St 60, St 90 and St 120, increasing from $6 \mathrm{~g} \mathrm{DW} \mathrm{m}^{-2}$ in St 60 to about $300 \mathrm{~g} \mathrm{DW} \mathrm{m}^{-2}$ in St 90 and St 120 (Tukey-Kramer, $<<0.05$; Figure $3 b$ ). Any other species of aquatic macrophytes was not observed during this study.

The sampling station with higher values of chlorophyll- $a$ in waters (St 30) also showed significantly higher pelagic GPP (Tukey-Kramer, $\mathrm{p}<0.05$; Figure 4), while R were significantly more intense in St 02 followed by a strong decline mainly in St 60, St 90 and St 120 (Tukey-Kramer, $\mathrm{p}<0.05$; Figure 4). Consequently, the pelagic NPP showed net heterotrophy in St 02 and St 15, net autotrophy in St 30 and St 60, and values next to equilibrium in St 90 and St 120 (Tukey-Kramer, $\mathrm{p}<0.05$; Figure 4).

\section{Discussion}

Dredging activities provided drastic short-term changes in waters of the Imboassica Stream during our study, as indicated by the substantially higher values of suspended solids and nutrients soon after (St 02), and further consistent temporal variation among all sampling stations. This confirms that dredging represents a catastrophic disturbance on the water quality (Lohrer and Wetz, 2003; Bemvenuti et al., 2005), altering well-known drivers on ecosystem functioning and the organic matter cycling in aquatic environments (Cole et al., 2000, 2007). Here, the recent removal of organic-enriched sediments (Petrucio et al., 1997) from the Imboassica Stream (St 02) was also related to more intense metabolic rates, including the most heterotrophic NPP and highest $\mathrm{R}$ among stations. On the other hand, this contrasted with the general positive relationship between higher nutrient

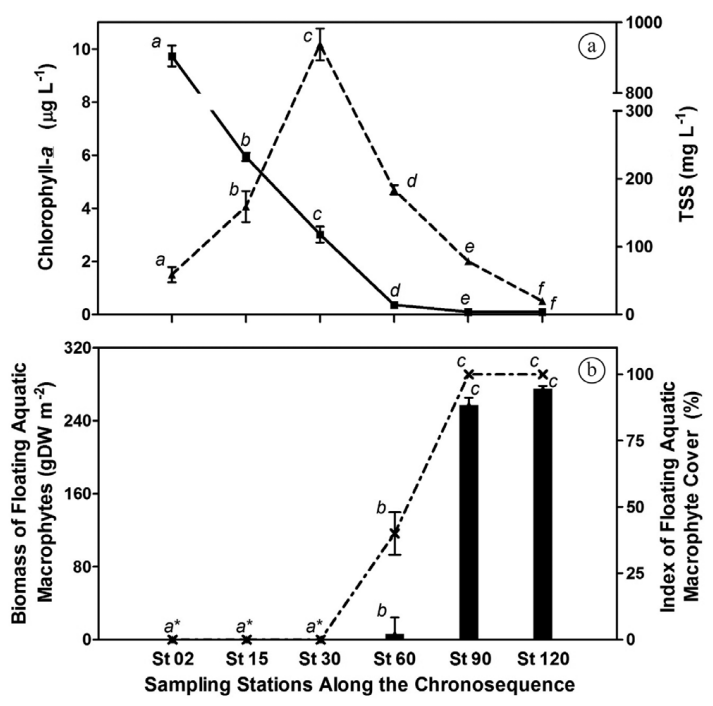

Figure 3. (a) total suspended solids (TSS; unbroken line, filled square) with chlorophyll- $a$ (dashed line, filled triangle), and (b) biomass (black bars) with cover index (dash-dot line, crosses) of floating aquatic macrophytes in waters of the downstream of the Imboassica Stream. Values are the average \pm standard error (SE). The same letters indicate non-significant differences for each variable among sampling stations ( $\mathrm{n}=4$; Tukey-Kramer, $\mathrm{p}>0.05)$, and the asterisks $(*)$ those stations showing null values in all samples for both biomass and cover index.

Table 1. Nutrient concentrations in each sampling station. Values are in $\mu \mathrm{mol} \mathrm{L}{ }^{-1}$.

\begin{tabular}{ccccccc}
\hline $\begin{array}{c}\text { Sampling } \\
\text { Stations }\end{array}$ & Ammonium & Nitrate & $\begin{array}{c}\text { Dissolved } \\
\text { Nitrogen }\end{array}$ & $\begin{array}{c}\text { Total } \\
\text { Nitrogen }\end{array}$ & $\begin{array}{c}\text { Dissolved } \\
\text { Phosphorus }\end{array}$ & $\begin{array}{c}\text { Total } \\
\text { Phosphorus }\end{array}$ \\
\hline St 02 & $43.3^{\mathrm{a}}$ & $3.3^{\mathrm{a}}$ & $54.2^{\mathrm{a}}$ & $170.6^{\mathrm{a}}$ & $6.6^{\mathrm{a}}$ & $6.6^{\mathrm{a}}$ \\
St 15 & $1.3^{\mathrm{b}}$ & $2.3^{\mathrm{b}}$ & $13.3^{\mathrm{b}}$ & $15.1^{\mathrm{b}}$ & $0.6^{\mathrm{b}}$ & $0.6^{\mathrm{b}}$ \\
St 30 & $3.1^{\mathrm{c}}$ & $0.8^{\mathrm{c}}$ & $20.4^{\mathrm{b}}$ & $50.2^{\mathrm{c}}$ & $0.8^{\mathrm{b}}$ & $1.1^{\mathrm{c}}$ \\
St 60 & $1.3^{\mathrm{b}}$ & $0.3^{\mathrm{d}}$ & $15.6^{\mathrm{b}}$ & $16.5^{\mathrm{b}}$ & $0.3^{\mathrm{d}}$ & $0.6^{\mathrm{b}}$ \\
St 90 & $4.2^{\mathrm{c}}$ & $1.4^{\mathrm{c}}$ & $17.2^{\mathrm{b}}$ & $22.1^{\mathrm{b}}$ & $1.2^{\mathrm{c}}$ & $1.3^{\mathrm{c}}$ \\
St 120 & $0.9^{\mathrm{b}}$ & $0.4^{\mathrm{d}}$ & $8.0^{\mathrm{c}}$ & $13.8^{\mathrm{b}}$ & $0.2^{\mathrm{d}}$ & $0.2^{\mathrm{d}}$ \\
\hline
\end{tabular}

The same letters indicate non-significant differences for each variable among sampling stations ( $\mathrm{n}=4$; Tukey-Kramer, $\mathrm{p}>0.05$ ). 


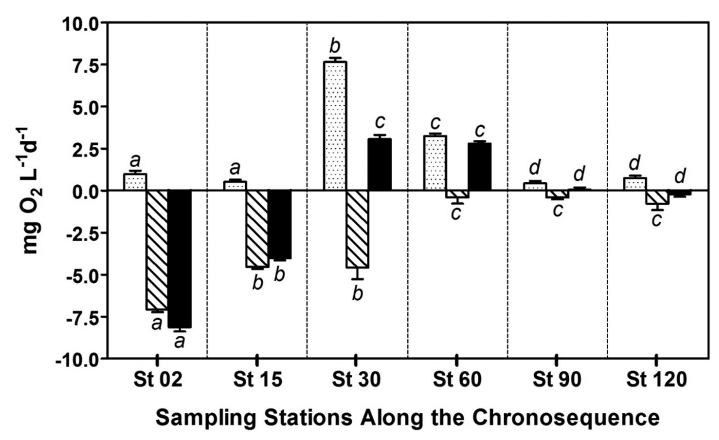

Figure 4. Metabolic rates in waters of the downstream of the Imboassica Stream: Gross Primary Production (GPP; dotted bars), Respiration (R, striped bars), and Net Primary Production (NPP; filled bars). Values are the average \pm SE. The same letters indicate non-significant differences for each variable among sampling stations $(n=4$; Tukey-Kramer, $\mathrm{p}>0.05$ ). Positive values of NPP represent net autotrophy and those negative the net heterotrophy.

levels and the net aquatic autotrophy (Duarte and Agusti, 1998; Biddanda et al., 2001), but confirmed that highly eutrophic and organic-enriched conditions may result in the persistence or even intensification of the heterotrophic status in tropical inland waters (Marotta et al., 2010a, 2012). These results might be attributed to resuspended organic matter from the bottom blocking light radiation to aquatic autotrophs (Roland and Esteves, 1998; Williamson et al., 1999) and supporting pelagic respiration, an imbalance that could explain net heterotrophy in nutrient-enriched waters (Cole et al., 2000).

Also, over time, the pelagic biological activity removes nutrients (Saunders and Kalff, 2001), while physical sedimentation plays an important role to decrease both TSS and nutrients in low-turbulence waters (Biddanda and Cotner, 2002). Further, intermediate levels of nutrients under low light attenuation by TSS and macrophytes potentially supported higher phytoplankton biomass, pelagic GPP and the subsequent net autotrophy in waters of St 30 comparing with stations more recently dredged (St 02 and St 15).

In contrast to higher algae biomass and pelagic primary production in St 30, other conditions contributed to reduce them in sampling stations where dredge had been carried out previously (St 60, St 90 and St 120). Despite similar TSS and nutrients in waters, St 60 showed a substantially lower pelagic GPP and phytoplankton biomass than St 30 . The nutrient availability by sewage discharges (Marotta et al., 2009a) and absence of shading by riparian vegetation (Wallace et al., 1997) could stimulate the floating aquatic vegetation (e.g. S. auriculata), conditions that were observed in the Imboassica Stream after dredging. Floating aquatic macrophytes covered $100 \%$ of water surface in St 90 and St 120, which can intensely reduce light penetration light into waters (Scheffer et al., 2003). Indeed, the presence of $S$. auriculata on waters was related to the lowest pelagic chlorophyll- $a$ and primary

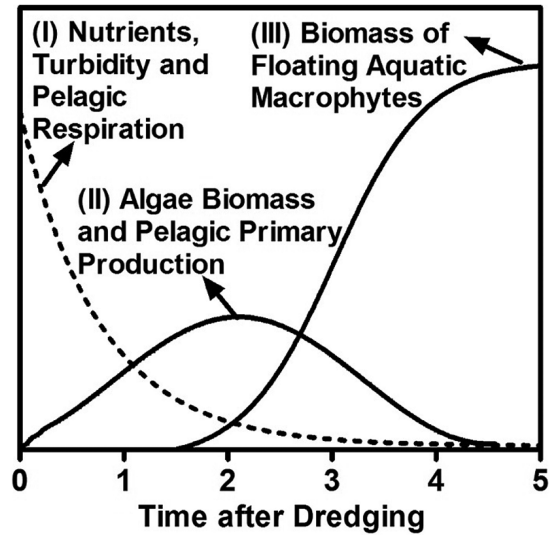

Figure 5. Conceptual model for catastrophic shifts in water quality and metabolic rates after dredging in tropical low-flow streams, including short-term trends for: (I) pelagic respiration, nutrients and turbidity, (II) algae biomass and pelagic primary production, and (III) biomass of floating aquatic macrophytes.

production in our study. In addition, the lower pelagic $\mathrm{R}$ observed in St 90 and St 120 may be further attributed to our sampling after the high sedimentation expected in non-turbulent waters (Roland and Esteves, 1998; Biddanda and Cotner, 2002), and below the very thin surface depth where organic matter is retained in between floating roots of the aquatic macrophytes (Mann and Wetzel, 1996). Overall, this might have contribute to changes in NPP from a net autotrophy in St 30 and a net equilibrium with floating macrophytes gradually covering the water surface in St 60, St 90 and St 120.

These results confirmed that metabolic rates in low-flow aquatic ecosystems may be highly dynamic (Staehr and Sand-Jensen, 2007; Marotta et al., 2010a), showing catastrophic shifts (Scheffer et al., 2001) among different metabolic balances stimulated under warmer tropical conditions (Marotta et al., 2010b). Small tropical downstreams might show three rapid stages for the pelagic production following the catastrophic disturbance by dredging (Conceptual Model, Figure 5): (I) a strongly heterotrophic NPP coupled to an intense respiration, probably supported by the high resuspended organic sediments and nutrients from the bottom; (II) a strongly autotrophic NPP coupled to an intense high primary production favored by high nutrient levels and low solar light attenuation by suspended solids or aquatic macrophytes; and (III) a NPP next to the equilibrium coupled to low pelagic GPP and R rates due to, respectively, shading by aquatic macrophytes and high sedimentation of particulate matter.

Therefore, floating aquatic macrophytes dominated downstream here over very short-term after dredging, representing a significant source of organic matter that could be buried in the aquatic bottom sediment (Engle et al., 2008). Other human-induced conditions of the Imboassica downstream during the study (e.g. high 
nutrients availability, low flow and no light shading to algae by the absence of riparian vegetation) might also have increased the magnitude of metabolic responses after catastrophic disturbances. Our results support that small streams might show catastrophic shifts between net autotrophy and heterotrophy after dredging, reflecting potentially important implications on organic matter cycling and silting up controls in extensive inland flooded areas at low latitudes.

\section{Acknowledgements}

This research was financed by funds from the Brazilian research agencies FAPERJ, CAPES and CNPq. AE-P receives a Researcher fellowship from $\mathrm{CNPq}$ and a Cientista do Nosso Estado fellowship from FAPERJ. HM receives a Jovem Cientusta do Nosso Estado fellowship from FAPERJ.

\section{References}

AMERICAN PUBLIC HEALTH ASSOCIATION - APHA, 1992. Standard methods for the examination of water and wastewater. 18th ed. Washington.

AZAM, F., 1998. Microbial control of oceanic carbon flux: the plot thickens. Science, vol. 280, no. 5364, pp. 694-696. http:// dx.doi.org/10.1126/science.280.5364.694.

BEMVENUTI, C.E., ANGONESI, L.G. and GANDRA, M.S., 2005. Effects of dredging operations on soft bottom macrofauna in a harbor in the patos lagoon estuarine region of southern brazil. Brazilian Journal of Biology $=$ Revista Brasileira de Biologia, vol. 63, no. 4, pp. 573-581. PMid:16532180.

BIDDANDA, B., OGDAHL, M. and COTNER, J., 2001. Dominance of bacterial metabolism in oligotrophic relative to eutrophic waters. Limnology and Oceanography, vol. 46, no. 3, pp. 730-739. http://dx.doi.org/10.4319/lo.2001.46.3.0730.

BIDDANDA, B.A. and COTNER, J.B., 2002. Love handles in aquatic ecosystems: the role of dissolved organic carbon drawdown, resuspended sediments, and terrigenous inputs in the carbon balance of Lake Michigan. Ecosystems, vol. 5, no. 5, pp. 431-445. http://dx.doi.org/10.1007/s10021-002-0163-z.

CARMOUZE, J.P., KNOPPERS, B. and VASCONCELOS, P., 1991. Metabolism of a subtropical Brazilian Lagoon. Biogeochemistry, vol. 14, no. 2, pp. 129-148. http://dx.doi.org/10.1007/BF00002902.

CASATTI, L., LANGEANI, F., SILVA, A.M. and CASTRO, R.M., 2006. Stream fish, water and habitat quality in a pasture dominated basin, southeastern Brazil. Brazilian Journal of Biology = Revista Brasileira de Biologia, vol. 66, no. 2B, pp. 681-696. http://dx.doi.org/10.1590/S1519-69842006000400012. PMid:16906300.

CHAPIN III, F.S., WOODWELL, G.M., RANDERSON, J.T., RASTETTER, E.B., LOVETT, G.M., BALDOCCHI, D.D., CLARK, D.A., HARMON, M.E., SCHIMEL, D.S., VALENTINI, R., WIRTH, C., ABER, J.D., COLE, J.J., GOULDEN, M.L., HARDEN, J.W., HEIMANN, M., HOWARTH, R.W., MATSON, P.A., MCGUIRE, A.D., MELILLO, J.M., MOONEY, H.A., NEFF, J.C., HOUGHTON, R.A., PACE, M.L., RYAN, M.G., RUNNING, S.W., SALA, O.E., SCHLESINGER, W.H. and SCHULZE, E.D., 2006. Reconciling carbon-cycle concepts, terminology, and methods. Ecosystems, vol. 9, no. 7, pp. 1041-1050. http:// dx.doi.org/10.1007/s10021-005-0105-7.

COLE, J.J., PACE, M.L., CARPENTER, S.R. and KITCHELL, J.F., 2000. Persistence of net heterotrophy in lakes during nutrient addition and food web manipulations. Limnology and Oceanography, vol. 45, no. 8, pp. 1718-1730. http://dx.doi. org/10.4319/lo.2000.45.8.1718.

COLE, J.J., PRAIRIE, Y.T., CARACO, N.F., MCDOWELL, W.H., TRANVIK, L.J., STRIEGL, R.G., DUARTE, C.M., KORTELAINEN, P., DOWNING, J.A., MIDDELBURG, J.J. and MELACK, J., 2007. Plumbing the global carbon cycle: integrating inland waters into the terrestrial carbon budget. Ecosystems, vol. 10, no. 1, pp. 171-184. http://dx.doi.org/10.1007/s10021-006-9013-8.

COWLES, H.C., 1899. The ecological relations of the vegetation of the sand dunes of Lake Michigan. Botanical Gazette, vol. 25, no. 2, pp. 95-117. http://dx.doi.org/10.1086/327796.

DAVIDSON, E.A., ARAÚJO, A.C., ARTAXO, P., BALCH, J.K., BROWN, I.F., C. BUSTAMANTE, M.M., COE, M.T., DEFRIES, R.S., KELLER, M., LONGO, M., MUNGER, J.W., SCHROEDER, W., SOARES-FILHO, B.S., SOUZA, C.M. and WOFSY, S.C., 2012. The Amazon basin in transition. Nature, vol. 481, no. 7381, pp. 321-328. http://dx.doi.org/10.1038/ nature10717. PMid:22258611.

DILLON, M.E., WANG, G. and HUEY, R.B., 2010. Global metabolic impacts of recent climate warming. Nature, vol. 467, no. 7316, pp. 704-706. http://dx.doi.org/10.1038/nature09407. PMid:20930843.

DUARTE, C.M. and AGUSTI, S., 1998. The CO2 balance of unproductive aquatic ecosystems. Science, vol. 281, no. 5374, pp. 234-236. http://dx.doi.org/10.1126/science.281.5374.234. PMid:9657712.

ENGLE, D.L., MELACK, J.M., DOYLE, R.D. and FISHER, T.R., 2008. High rates of net primary production and turnover of floating grasses on the Amazon floodplain: implications for aquatic respiration and regional CO2 flux. Global Change Biology, vol. 14 , no. 2 , pp. 369-381. http://dx.doi.org/10.1111/j.13652486.2007.01481.x.

ENGSTROM, D.R., FRITZ, S.C., ALMENDINGER, J.E. and JUGGINS, S., 2000. Chemical and biological trends during lake evolution in recently deglaciated terrain. Nature, vol. 408, no. 6809 , pp. 161-166. http://dx.doi.org/10.1038/35041500. PMid:11089963.

GOLTERMAN, H.L., CLYMO, R.S. and OHNSTAD, M.A.M., 1978. Methods for physical and chemical analysis of fresh water. Oxford: Blackwell Scientific.

HARTZELL, J.L. and JORDAN, T.E., 2012. Shifts in the relative availability of phosphorus and nitrogen along estuarine salinity gradients. Biogeochemistry, vol. 107, no. 1-3, pp. 489-500. http:// dx.doi.org/10.1007/s10533-010-9548-9.

INSTITUTO NACIONAL DE METEOROLOGIA - INMET, 1992. Relatório Anual do Instituto Nacional de Meteorologia: 1991. Rio de Janeiro.

JIANG, J.G. and SHEN, Y.F., 2006. Estimation of the natural purification rate of a eutrophic lake after pollutant removal. Ecological Engineering, vol. 28, no. 2, pp. 166-173. http://dx.doi. org/10.1016/j.ecoleng.2006.06.002.

KNOLL, L.B., VANNI, M.J. and RENWICK, W.H., 2003. Phytoplankton primary production and photosynthetic parameters in reservoirs along a gradient of watershed land use. Limnology 
and Oceanography, vol. 48, no. 2, pp. 608-617. http://dx.doi. org/10.4319/1o.2003.48.2.0608.

LICHTER, J., 1998. Primary succession and forest development on coastal Lake Michigan sand dunes. Ecological Monographs, vol. 68 , pp. 487-510.

LOHRER, A.M. and WETZ, J.J., 2003. Dredging-induced nutrient release from sediments to the water column in a southeastern saltmarsh tidal creek. Marine Pollution Bulletin, vol. 46, no. 9, pp. 1156-1163. http://dx.doi.org/10.1016/S0025-326X(03)00167-X. PMid:12932497.

LOWRIE, D.C., 1948. The ecological succession of spiders of the Chicago area dunes. Ecology, vol. 29, no. 3, pp. 334-351. http://dx.doi.org/10.2307/1930993.

MACKERETH, F.J.H., HERON, J. and TALLING, J.F., 1978. Water analysis: some revised methods for limnologists. Cumbria: Freshwater Biological Association. Freshwater Biological Association Scientific Publication, no. 36.

MANN, C.J. and WETZEL, R.G., 1996. Loading and utilization of dissolved organic carbon from emergent macrophytes. Aquatic Botany, vol. 53, no. 1-2, pp. 61-72. http://dx.doi.org/10.1016/03043770(95)01012-2.

MAROTTA, H., BENTO, L., ESTEVES, F.A. and ENRICHPRAST, A., 2009a. Whole ecosystem evidence of eutrophication enhancement by wetland dredging in a shallow tropical lake. Estuaries and Coasts, vol. 32, no. 4, pp. 654-660. http://dx.doi. org/10.1007/s12237-009-9152-1.

MAROTTA, H., DUARTE, C.M., SOBEK, S. and ENRICHPRAST, A., 2009b. Large CO2 disequilibria in tropical lakes. Global Biogeochemical Cycles, vol. 23, pp. 1-4.

MAROTTA, H., DUARTE, C.M., GUIMARAES-SOUZA, B.A. and ENRICH-PRAST, A., 2012. Synergistic control of $\mathrm{CO} 2$ emissions by fish and nutrients in a humic tropical lake. Oecologia, vol. 168, no. 3, pp. 839-847. http://dx.doi.org/10.1007/ s00442-011-2131-9. PMid:21983711.

MAROTTA, H., DUARTE, C.M., MEIRELLES-PEREIRA, F., BENTO, L., ESTEVES, F.A. and ENRICH-PRAST, A., 2010a. Long-term variability of $\mathrm{CO} 2$ in two shallow tropical lakes experiencing episodic eutrophication and acidification events. Ecosystems, vol. 13, no. 3, pp. 382-392. http://dx.doi.org/10.1007/ s10021-010-9325-6.

MAROTTA, H., DUARTE, C.M., PINHO, L. and ENRICHPRAST, A., 2010b. Rainfall leads to increased pCO(2) in Brazilian coastal lakes. Biogeosciences, vol. 7, no. 5, pp. 1607-1614. http:// dx.doi.org/10.5194/bg-7-1607-2010.

MOREIRA-TURCQ, P., JOUANNEAU, J., TURCQ, B., SEYLER, P., WEBER, O. and GUYOT, J.-L., 2004. Carbon sedimentation at Lago Grande de Curuai, a floodplain lake in the low Amazon region: insights into sedimentation rates. Palaeogeography, Palaeoclimatology, Palaeoecology, vol. 214, no. 1-2, pp. 27-40. http://dx.doi.org/10.1016/j.palaeo.2004.06.013.

NISLOW, K.H. and LOWE, W.H., 2006. Influences of logging history and riparian forest characteristics on macroinvertebrates and brook trout (Salvelinus fontinalis) in headwater streams (New Hampshire, USA). Freshwater Biology, vol. 51, no. 2, pp. 388-397. http://dx.doi.org/10.1111/j.1365-2427.2005.01492.x.

NUSCH, E.A. and PALME, G., 1975. Biologische methoden für die praxis der gewässeruntersuchung: bestimmung des chlorophyll-a und phaeopigmentgehaltes in oberflächenwasser. GWF-Wasser/ Abwasser, vol. 116, pp. 562-565.
PETRUCIO, M.M., ENRICH-PRAST, A. and ESTEVES, F.A., 1997. Vertical distribution of nutrients in the sediment of a brazilian coastal lagoon (Imboassica Lagoon, Rio de Janeiro). Acta Limnologica Brasiliensia, vol. 9, pp. 117-124.

RAM, A.S.P., NAIR, S. and CHANDRAMOHAN, D., 2003. Seasonal shift in net ecosystem production in a tropical estuary. Limnology and Oceanography, vol. 48, no. 4, pp. 1601-1607. http://dx.doi.org/10.4319/lo.2003.48.4.1601.

ROLAND, F. and ESTEVES, F.D., 1998. Effects of bauxite tailing on PAR attenuation in an Amazonian crystalline water lake. Hydrobiologia, vol. 377, no. 1-3, pp. 1-7. http://dx.doi. org/10.1023/A:1003252805671.

RÖRIG, L.R.A., TUNDISI, J.G., SCHETTINI, C.A.F., PEREIRAFILHO, J., MENEZES, J.T., ALMEIDA, T.C.M., URBAN, S.R., RADETSKI, C.M., SPERB, R.C., STRAMOSK, C.A., MACEDO, R.S., CASTRO-SILVA, M.A. and PEREZ, J.A.A., 2007. From a water resource to a point pollution source: the daily journey of a coastal urban stream. Brazilian Journal of Biology = Revista Brasileira de Biologia, vol. 67, no. 4, pp. 597-609. http://dx.doi. org/10.1590/S1519-69842007000400003. PMid:18278310.

SAUNDERS, D.L. and KALFF, J., 2001. Nitrogen retention in wetlands, lakes and rivers. Hydrobiologia, vol. 443, no. 1-3, pp. 205-212. http://dx.doi.org/10.1023/A:1017506914063.

SCHEFFER, M., CARPENTER, S., FOLEY, J.A., FOLKE, C. and WALKER, B., 2001. Catastrophic shifts in ecosystems. Nature, vol. 413, no. 6856, pp. 591-596. http://dx.doi.org/10.1038/35098000. PMid:11595939.

SCHEFFER, M., SZABO, S., GRAGNANI, A., VAN NES, E.H., RINALDI, S., KAUTSKY, N., NORBERG, J., ROIJACKERS, R.M.M. and FRANKEN, R.J.M., 2003. Floating plant dominance as a stable state. Proceedings of the National Academy of Sciences of the United States of America, vol. 100, no. 7, pp. 4040-4045. http://dx.doi.org/10.1073/pnas.0737918100. PMid:12634429.

SCHINDLER, D.W., 2006. Recent advances in the understanding and management of eutrophication. Limnology and Oceanography, vol. 51, no. 1, pp. 356-363. http://dx.doi.org/10.4319/lo.2006.51.1_ part_2.0356.

STAEHR, P.A. and SAND-JENSEN, K., 2007. Temporal dynamics and regulation of lake metabolism. Limnology and Oceanography, vol. 52, no. 1, pp. 108-120. http://dx.doi. org/10.4319/lo.2007.52.1.0108.

WALLACE, J.B., EGGERT, S.L., MEYER, J.L. and WEBSTER, J.R., 1997. Multiple trophic levels of a forest stream linked to terrestrial litter inputs. Science, vol. 277, no. 5322, pp. 102-104. http://dx.doi.org/10.1126/science.277.5322.102.

WARDLE, D.A., WALKER, L.R. and BARDGETT, R.D., 2004. Ecosystem properties and forest decline in contrasting long-term chronosequences. Science, vol. 305, no. 5683, pp. 509-513. http:// dx.doi.org/10.1126/science.1098778. PMid:15205475.

WETZEL, R.G. and LIKENS, G.E., 2000. Limnological analyses. 3rd ed. New York: Springer.

WILLIAMSON, C.E., MORRIS, D.P., PACE, M.L. and OLSON, A.G., 1999. Dissolved organic carbon and nutrients as regulators of lake ecosystems: resurrecbtion of a more integrated paradigm. Limnology and Oceanography, vol. 44, no. 3, pp. 795-803. http:// dx.doi.org/10.4319/1o.1999.44.3_part_2.0795.

WOHLERS, J., ENGEL, A., ZOLLNER, E., BREITHAUPT, P., JURGENS, K., HOPPE, H.G., SOMMER, U. and RIEBESELL, U., 2009. Changes in biogenic carbon flow in response to sea 
surface warming. Proceedings of the National Academy of Sciences of the United States of America, vol. 106, no. 17, pp. 7067-7072. http://dx.doi.org/10.1073/pnas.0812743106. PMid:19359482.

ZAR, J.H., 1996. Biostatistical analysis. 3rd ed. New Jersey: Prentice Hall.
ZONA, D., OECHEL, W.C., PETERSON, K.M., CLEMENTS, R.J., PAW U, K.T. and USTIN, S.L., 2010. Characterization of the carbon fluxes of a vegetated drained lake basin chronosequence on the Alaskan Arctic Coastal Plain. Global Change Biology, vol. 16, no. 6, pp. 1870-1882. http://dx.doi.org/10.1111/j.13652486.2009.02107.x. 